\title{
Appraisal and Party Positioning in Parliamentary Debates: A Usage-Based Critical Discourse Analysis
}

\author{
Anissa Berracheche ${ }^{1}$ \\ ${ }^{1}$ LECSeL-Linguistique Empirique: Cognition, Société et Langage, Université Paris 8 Vincennes-Saint-Denis, \\ Paris, France \\ Correspondence: Anissa Berracheche, LECSeL, Université Paris 8 Vincennes-Saint-Denis, Paris, France. E-mail: \\ aberracheche@gmail.com
}

Received: August 22, 2020

Accepted: September 21, $2020 \quad$ Online Published: October 8, 2020

doi:10.5539/ijel.v10n6p322

URL: https://doi.org/10.5539/ijel.v10n6p322

\begin{abstract}
This article presents a corpus-driven study of evaluative discourses surrounding asylum seekers in parliamentary debates. It explores how Australian political parties have expressed unfavorable attitudes toward asylum seekers. These attitudes are operationalized by implementing Martin and White's appraisal framework, which comprises affectual (affect), ethical (judgment), and aesthetic (appreciation) values. The findings reveal that the subcategories of affect, judgment, and appreciation are strategically deployed by both right- and left-wing parties. The right-wing discourse, conveying ethical values, emphasizes the difference between "in" and "out" groups, whereas the left-wing discourse, engaged in affectual values, demonstrates their humanitarian side. The study has also a methodological focus, namely, testing the feasibility of the behavioral profile approach in critical discourse analysis to obtain more replicable and reliable quantitative results. The method consists of the manual annotation of the corpus and multivariate statistical analysis.
\end{abstract}

Keywords: appraisal, corpus linguistics, manual annotation, statistics, critical discourse analysis

\section{Introduction}

In contemporary society, the issues concerning asylum seekers are crucial. Asylum seekers comprise those who flee persecution in their home countries - some attempting arduous journeys - to reach safe countries wherein they apply for asylum. However, asylum seekers in these countries often face harsh asylum policies, namely restrictions, detention, deportation, expulsion, or long waiting processes. One of the most important ways in which asylum seekers are victimized is through political discourse. Therefore, understanding the issues involved in asylum seeking is crucial for individuals, policymakers, and society at large.

Politicians contribute to the pervasive attitudes toward asylum seekers expressed by individuals within society. They play a fundamental role in the official definition and construction of asylum seekers. These definitions arise, in part, from their official stance and personal attitudes, which shape public opinion through various forms of communications. Therefore, understanding how attitudes are formulated and manipulated by politicians is crucial to determine our responses to asylum seekers as individuals and as society.

This paper uses the appraisal framework for a comparative study of left- and right-wing Australian parties. It aims to uncover aspects of interpersonal (power) relations and, particularly, to shed light on the different attitudinal strategies to legitimate negative attitudes toward asylum seekers. It also aims to answer to the following questions:

(i) Are asylum issues treated differently in the left- and right-wing discourses and, if so, how can we make sense of this difference?

(ii) To what extent can an evaluative language help us understand the ideological profile of political positioning?

To achieve a fuller understanding of the potential communicative tools of appraisal and their effects, the results are interpreted using the critical discourse analysis (CDA). $\mathrm{CDA}$ is crucial for us to understand social power and dominance as well as how dominant groups use attitudes, ideologies, values, and norms to control the public opinion and legitimize racist policies (van Dijk, 1993).

In recent decades, the study of attitude has attracted great attention in linguistics and has been examined in various forms, namely stance (Biber \& Finegan, 1989), evaluation (Thompson \& Hunston, 2000; Hunston, 2010; 
Bednarek, 2006), and appraisal (White, 2002; Martin \& White, 2005). The attitude in migration discourse as an interpersonal emerged structure has also been investigated (Hart, 2014; Coffin \& O'Halloran, 2006), yet this aspect remains less explored compared to a large number of studies focused on the ideational function, namely how texts describe the representation of migrants, refugees, and asylum seekers (e.g., Khosravinik, 2009, 2010; Baker et al., 2008; Gabrielatos \& Baker, 2008; van Leeuwen \& Wodak, 1999; van Leeuwen, 1996). Applying the appraisal framework, this study contributes to the literature by considering the interpersonal function. Therefore, it extends the research on attitude to the study of political party positioning and identification.

The general aim of this paper is to understand some of the mechanisms of attitude in appraisal, which shape intraparty ideological discourses. More precisely, it seeks to understand how such political discourses are involved in the enactment, confirmation, or challenge of attitudes about ethnic groups. In addition to the worthwhile analytical goal of improving the tools to extract attitudes and covert expressions within the discourses, this study has also a methodological aim, that is, demonstrating the feasibility of the behavioral profile approach to improve the CDA method. Qualitative methods have been criticized as focusing on a selected sample to suit the hypothesis of the study, whereas purely quantitative keyword analysis has been criticized as neglecting the context by focusing on repetitive items in language use. This study, drawing on the corpus-driven method, applies the behavioral profile approach developed in cognitive linguistics (Geeraerts, Grondelaers, \& Bakema, 1994; Gries \& Stefanowitsch, 2007; Glynn \& Robinson, 2014). In the first step, the text is annotated for several discursive factors, whicht result in a set of metadata independent of the actual language. The results of the discourse analysis are then analyzed statistically, using statistical tools to incorporate reliable interpretation and reduplicated results in CDA.

The remainder of this paper is structured as follows. Section 1.1 describes the theoretical background of the study, reviewing previous discourse analyses of parliamentary discourses (Section 1.1.1) and an overview of appraisal theory (Section 1.2.1). Section 2 outlines the method and data. The final two sections, Sections 3 and 4, report the results of the study and provide a discussion, respectively.

\subsection{Background}

\subsubsection{Parliamentary Discourse}

The parliament has a prominent role in the democratic process of western countries. It is a directly elected body of the government that holds legislative power. The parliament sits to enact laws, scrutinize government work, and debate national and international issues. It is mainly a place devoted to linguistic exchanges and discussions between the elected individuals who "display the various ideological visions, party political affiliations, institutional positions, and political agendas of members of parliament (MPs)" (Ilie, 2015, p. 1). The members of the parliament, therefore, construct multiple (political) identities, such as representing the public, acting on behalf of the government, defending party interests and beliefs, and so on. They may also collaborate with others who are politically similar, confront ideologies, and act to legitimate truth in their actions and reactions to achieve a common view.

Parliamentary debates have certain discursive properties that may distinguish them from other genres of political language. Parliamentary discourse comprises various parts: the politicians, leading actors deeply engaged in the act of debating; the wider audience of parliamentarians and the public outside the parliament who are not directly involved in the political scene; and the context, which may include time, space, goals, and implications (van Dijk, 1997). However, parliamentary discourse is considered to be an incessant "struggle for power, between those who seek to assert and maintain their power and those who seek to resist it" (Chilton \& Schäffner, 2002, p. 3). Politicians, therefore, use a variety of strategies to "represent" the world in their minds as well as how to "interpret" it. These strategies emerge from the use and manipulation of language.

Although several previous studies have focused on parliamentary discourse in CDA (e.g., Slembrouck, 1992; Carbó, 1992, 2004; Wodak \& van Dijk, 2000; Bayley, 2004; Ilie, 1999, 2004, 2005, 2010; Baker, 2004; van der Valk, 2000, 2003; Rojo \& van Dijk, 1997), they have mainly considered the ideological potential of discourse using different analytical strategies, such as style, grammar, rhetoric (van Dijk, 2000), argumentation (Antelmi \& Santulli, 2010), and hedging (Ilie, 2010). Recent studies of parliamentary debates have turned to the interpersonal aspects of discourse. For instance, Bevitori (2005) examined the notion of engagement in appraisal to explain how the authorial voice enters into a dialogic relationship of alignment and disalignment with the quoted voices. Jakaza and Visser (2016) investigated how attitudinal meanings are communicated in argumentative discourse to resolve a difference of opinion and turn the debate in one's favor. Gruber (2012) stated that the expressed attitude depends on whether a speaker is in opposition or a governmental member of parlaiment. This study contributes to the literature drawing on attitude in appraisal to understand how the affectual, ethical, and aesthetic values toward asylum seekers determine party affiliation. 
If we are to understand intraparty discourses on asylum seekers, we first need to understand how politicians are interpersonally engaged in various ideological commitments.

\subsubsection{Appraisal}

Systemic Functional Linguistics (Halliday \& Matthiessen, 1999; see also Eggins, 2004) explores three types of meaning: ideational, textual, and interpersonal metafunctions. The interpersonal source of language is not merely about negotiating and evaluating meaning - it also concerns the enactment of roles and relations. This interpersonal meaning gives rise to the appraisal framework (Martin \& White, 2005; White, 2015), which concerns attitudinal utterances, their intensity, and the dialogic aspects of propositions in their natural communicative contexts.

The appraisal framework differentiates among three categories of a system of values, namely attitude, engagement, and graduation. Attitude refers to a positive or negative value assigned to emotions and feelings. In engagement, the writer/speaker is engaged in a value position regarding their proposition to open or close the dialogical space for alternative voices. Graduation refers to amplifying or diminishing the value of positioning in attitude and engagement (White, 2015).

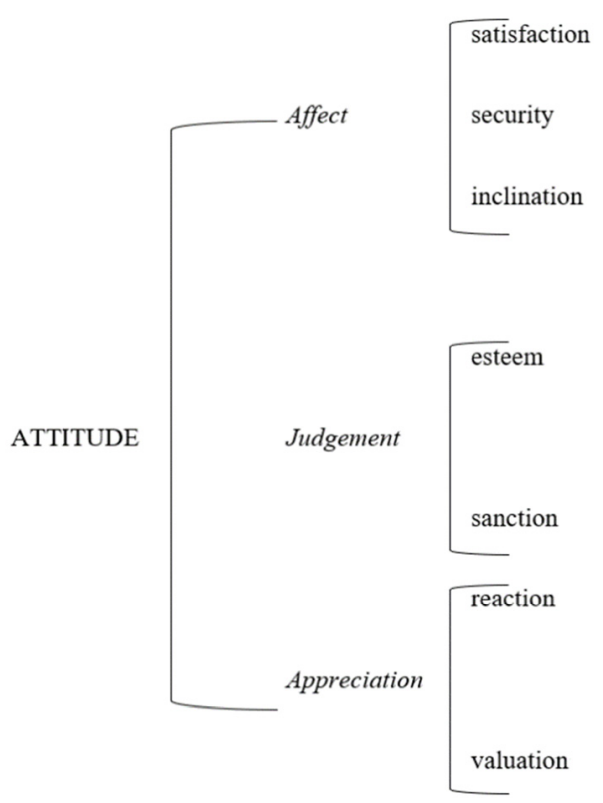

Figure 1. An overview of appraisal (adapted from Martin \& White, 2005)

Appraisal divides the evaluative resources of language into a coherent, systemic set of linguistic resources in which "each choice... acquires its meanings against the background of the other choices which could have been made" (Eggins, 2004, p. 3). This systemic network moves from coarse- to fine-grained sets of meanings. The evaluative meanings have a wide range of lexico-grammatical resources, comprising verbs, adjectives, adverbs, and nouns. I employ this framework to examine the attitudinal positioning of party leaders. Thus, the next subsection focuses on the categories of attitude more in detail and it is illustrated by examples from the corpus.

\subsubsection{Attitude}

As shown in Figure 1, Attitude systems are subdivided into three categories: affect, judgment, and appreciation.

Affect concerns the emotional reaction to behaviors, processes, or phenomena. It maps out three subcategories: dis/inclination, dis/satisfaction, and in/security. Inclination refers to a feeling of desire (Example 1). The satisfaction variable regards feelings of achievement of goals (Example 2). The security variable covers feelings of peace and anxiety with environmental and social well-being (Example 3).

(1) We absolutely want to get children out of detention. (Inclination) (16/03/2015, Tony Abbott: Prime minister, right-wing party)

(2) None is released into the Australian community until we are satisfied about their health, security and identity. (Satisfaction) (16/11/2009, Chris Evans: Senator, left-wing party) 
(3) They arrived safely, but in the last 12 months more than 300 people have not been so lucky. Two hundred people died in December. (Security) (28/06/2012, Clare Jason: MP, left-wing party)

Judgment is concerned with construing attitudes toward people's character and the way they behave according to various normative and ethical principles. The judgment attitude is divided into esteem and sanction. Esteem has to do with the normality of people's behaviors, capacity, and tenacity; it tends to be policed within the culture and it is generally grounded in shared social networks, such as family and friends. Sanction has to do with judging people's truthfulness and ethical values; it is codified in the values and regulations of society with penalties and punishments against those who do not obey them.

(4) What would you be doing if you really wanted to help the most vulnerable refugees? (Esteem) (26/08/2002, Philip Ruddock: minister, right-wing party)

(5) The changes relate particularly to people coming unauthorised by boat, seeking asylum. (Sanction) (13/06/2006, Amanda Vanstone: Senator, right-wing party)

Appreciation regards resources that construe the value of human-made things, processes, or natural and social phenomena. However, according to Bednarek (2006), appreciation may concern human beings when they are regarded as entities and when they are not evaluated in terms of their emotions or behaviors. This study focuses on two categories of appreciation, namely emotional reaction and social valuation. Emotional reaction concerns the positive or negative emotional impact of a process on people's attention. Social valuation concerns the negative or positive evaluation of social activities, conditions, processes, or phenomena.

(6) The threat of illegal arrivals by boat is very real. (Reaction) (28/03/2007, Kevin Andrews: MP, right-wing party)

(7) $[\ldots]$ then to ensure that they have the appropriate health, identity and security checks. (Valuation) (16/11/2009, Chris Evans: Senator, left-wing party)

\subsubsection{Challenges of Attitudinal Resources in Appraisal}

Appraisal was designed to capture the evaluative meaning in language; however, this meaning can be either conveyed overtly or expressed covertly. An overt attitude is "inscribed" by explicitly using attitudinal lexis, whereas a covert attitude is "invoked" by the ideational meaning expressed by factual information. Determining the covert attitude is a complex task that necessitates a particular reading position, which involves understanding the relevant linguistic and contextual factors and sharing the ideological position of the target readers. For instance, to detect and understand covert evaluation, Coffin and O'Halloran (2006) use intertextuality; this method aims to minimize the difficulties in interpreting the covert evaluation and reduce disagreement between analysts.

We will examine the differences between covert and overt attitudes in the following examples:

(8) Sri Lankans were caught by the Royal Australian Navy in international waters attempting to illegally reach Christmas Island. (21/03/2007, Kevin Andrews: MP, right-wing party)

(9) People paid the people smugglers up to $\$ \mathbf{U S 1 0 , 0 0 0}$ to be transported from Sri Lanka to Australia. (21/03/2007, Kevin Andrews: MP, right-wing party)

Both examples denote judgment-sanction. In the first example, the evaluative item "illegally" overtly expresses sanction: asylum seekers do not obey regulations. In the second example, the construction "paid the people smugglers up to $\$ 10,000$ " presupposes that asylum seekers illegally enter Australia. This interpretation is based on shared knowledge between the speaker and his target audience. The asylum seekers who should be helped are generally poor and needy, whereas those who pay this huge amount of money do not merit protection. Moreover, the latter group of people is not ethical since they are engaged in illegal activity with smugglers, and they do not share the same morals and ethics as Australian society. The assumption that poverty and need are criteria for asylum acceptance is shared among the target audience. Shared social norms and values allow politicians to interpret asylum seekers' entrance in a certain way and thereafter justify their reasons to reject asylum applications.

The next challenge in ascribing features of appraisal is that it is difficult to distinguish within the same example among affect, judgment, and appreciation. This "hybrid realization" (Martin \& White, 2005) reflects in an explicitly inscribed category of appraisal and implicitly invokes another. For instance, inscribed appreciation (evaluating things) can invoke a judgment of the performer of those things; contrarily, an inscribed judgment of the person can invoke an appreciation of the activity. This statement is exemplified below:

(10) This was a package deal. People paid the people smugglers up to $\$ U S 10,000$ to be transported from Sri Lanka to Australia. These are international criminal networks that operate on a high-profit basis and show no 
concern or care for the people they smuggle or the lives they endanger. The trade of people smuggling is odious, it is dangerous, it is repugnant and it is illegal, and it should be seen that way. The Australian government has done, and will continue to do, all in its power to prevent and deter the perpetrators of people smuggling activity. (21/03/2007, Kevin Andrews: MP, right-wing party)

The highlighted example provides us with enough context. It clearly states an overt appreciation reaction to the phenomenon of people smuggling; however, it invites the covert judgment of smugglers and asylum seekers who are involved in illegal/non-ethical behavior. This invoked judgment can be understood from contextual keywords such as "international criminal networks," "should be seen that way," and "prevent and deter the perpetrators." These terms invite the target readers to align with the politician's positioning to reject asylum seekers, seeing them as ethically different.

These challenges remain subject to analyst bias, which invites the analyst to search for novel methods.

\section{Methods}

\subsection{Data Collection}

The data for this study are derived from a publicly available corpus, the Hansard of Australian Parliament, an edited collection of transcripts of spoken debates. The Australian parliament was chosen because the issue of asylum seekers is a high-profile situation, which has been the subject of long and substantial debate in Australian society. The corpus consists of instances of parliamentarians' replies in the Question without Notice Session, which is a crucial session within parliamentary debates. The questioning session is considered more than a legislative activity; it is an opportunity for ministers to present their ideas and defend their party interests (Bayley, 2004). Additionally, the questions challenge and test ministers' political skills as "this confrontational dialogue fuels not only a theatrical stance and a role awareness of the interactants but also a sense of competitiveness" (Ilie, 2003, p. 26). The data can easily be retrieved from the Australian parliament website by entering the keywords "asylum seekers" using the Hansard's search function. Additional search criteria were the period (26 June 2002 to 12 October 2015), chambers (Senate and House of Representatives), and context (Questions without Notice), which yielded a large amount of data. The sample contains a random selection extracted from many politicians' replies during the Question without Notice sessions. Our corpus comprised 32,455 words spoken by MPs and senators. We highlighted 400 evaluative examples-both covert and overt evaluation-that refer to asylum seekers.

Quantitative corpus-driven methods of discourse analysis rely on data from real, natural, and spontaneous discourses produced in a natural communicative setting. The parliamentarians are challenged by unexpected and provocative questions. These questions are likely to be tough, having been designed to test their capacity to answer quickly and confidently. However, when speech is transcribed, it may lose some natural features such as hesitation, pauses, and self-correction. In addition, not all non-verbal processes can be coded verbally, such as facial expressions, intonation, pitch, and loudness. A negative attitude may be conveyed in different ways-as Van Dijk writes, "negative opinions about minority groups may be expressed and conveyed by intonation or gestures that may be inconsistent with seemingly 'tolerant' meanings" (van Dijk, 1993, p. 104).

\subsection{Behavioral Profile Approach to CDA}

The methods used in CDA have been criticized for several reasons. First, the analysis is based on the ideological commitments of the analysts (Widdowson, 1995), resulting in a biased interpretation. Second, data collection is usually not considered to be a specific phase of analysis in CDA; generally, there is no obvious distinction between data collection and data analysis.

To resolve this methodological debate, our approach to the usage-based CDA method proposes useful solutions with a focus on empirical data selection. Our specific approach to collecting and annotating data is based on observation. Then, data are manually annotated by adding metadata to the retrieved expressions to be able to restrict the interpretation. Moreover, statistical analysis assists the analyst in the explanation phase.

This method is abductive and pragmatic, and the annotation scheme is developed in line with the research questions. A constant movement between theory and the empirical data is advised. The sociocultural context is integrated into the interpretation based on the findings of the used explanatory and confirmatory techniques. Additionally, the method provides criteria to assess the quality of its findings, namely validity and reliability. Strict objectivity cannot be achieved in discourse analysis; however, this method limits prejudice and bias.

A variety of methods have been employed in CDA. They can be categorized as either qualitative or quantitative, depending on the way the data sources are approached. Qualitative methods were initially widely explored in CDA (e.g., Fairclough, 2001; Fairclough \& Wodak, 1997; van Dijk, 1995) based on a selective approach of small sample 
texts. Although this approach provides a manual contextual analysis of the texts, it has received some criticism because selective data generally suits the analyst's hypotheses. Interpretations of the results are, therefore, subject to ideological commitments (Widdowson, 1995; Mautner, 2005). Such methodological debates have given rise to a quantitative method based on large sets of authentic data, which are empirically selected and investigated.

The behavioral profile approach (Geeraerts et al., 1994; Glynn \& Fischer, 2010; Glynn \& Robinson, 2014), developed in line with the quantitative corpus-driven methods, can be relevant for CDA. This approach aims to combine close manual contextual analysis with multivariate statistical analysis. Manual annotation of the corpus consists of attributing linguistic information to the actual texts to reduce biased interpretation of the results whereas the quantitative statistical analysis is intended to identify complex patterns in the data and predict language use. The combined approach offers a systemic and replicable approach to CDA. Moreover, this method is pragmatic and allows the development of a coding schema in line with the research questions, moving continuously between theory and the data. It also integrates the sociocultural factors during data collection to facilitate the social interpretation of the findings. This approach attempts to shift the theoretical inherited questions in CDA (e.g., Fairclough, 1992; Fowler, 1991; van Dijk, 1991; van Leeuwen, 1996; Reisigl \& Wodak, 2001; Hart, 2010; Chilton, 2005) to the method-oriented problem (Baker et al., 2008).

This method has been successfully implemented in semantics and functions effectively in CDA. The first phase of the behavioral method is to operationalize the research question as a set of factors inspired by various theories (e.g., semantic, syntactic, and sociocultural factors). The second phase comprises a manual contextual analysis of contextualized examples of these features, resulting in a large metadata set. The next phase is interpreting the results of an empirical search by applying multivariate statistics. Glynn (2010, p. 263) justified the choice of his model, writing that "although these steps do not offer objectivity, they afford a means for verification and facilitate the empirical cycle by proposing hypotheses and testing them. Step one allows other researchers to check and improve upon existing analyses; step two increases accuracy; step three offers statistical significance and a measure of explanatory power." Accordingly, this method enhances the reliability of the analysis and results and grounds the search in empirical and scientific studies.

The following two sections, Section 2.2.1 and Section 2.2.2, describe the fundamental steps in the behavioral profile approach, that is, the manual contextual analysis and quantitative statistical analysis.

\subsubsection{Manual Contextual Analysis}

Contrary to a purely quantitative method, this method requires human intervention as the context is crucial to determine evaluative expressions, both overt and covert. The manual coding of the text assigns semantic and social features to the retrieved expressions. In this study, the coding is aided by the Microsoft Excel computer software.

This paper illustrates the procedures utilized to ensure accurate and reliable annotation in CDA. First, the research questions are formulated into a concise and simple coding scheme, offering a wide variety of ways to understand the data from distinct points of view. For instance, the choice of appraisal as a systemic set of meanings fits properly with the annotation task. Second, applying statistical analysis, the encoded corpus demonstrates the complexity of the data. However, the contextual manual annotation has its limitations; it is an exhausting and time-consuming task. Compared to purely automatic corpus analysis (concordance software), which can analyze an enormous amount of data, manual annotation is limited to a small sample of data. Because it is criticized for the potential of biased coding, it may not differ from other qualitative analysis approaches in CDA. Annotation, then, introduces the comprehension of the data and delimit data interpretation in an attempt to avoid biased and arbitrary results by using pre-determined linguistic and social factors.

\subsubsection{Quantitative Statistical Analysis}

CDA may benefit from applying statistical analysis to fundamental issues such as migration discourse, as this ensures a quantitative approach relying on the systematic collection of data and the empirical testing of a hypothesis. Thus, the next step in this quantitative method is to apply statistical analysis. The quantitative statistical analysis comprises two steps. First, exploratory statistical analysis (e.g., Hierarchical Cluster Analysis; Multiple/Binary Correspondence Analysis) allows exploration of the coherent pattern and matching of the introspective results. Second, confirmatory statistics (e.g., Logistic Regression Analysis; Log-linear analysis) allows one to verify and predict the findings. In summary, if the first step is to explore the main patterns in the data, the next step is to predict whether the effects observed in a corpus can be generalized to the population (Glynn, 2014).

The exploratory statistical device used in this analysis is the Binary Correspondence Analysis (BCA). BCA is a 
space reduction tool that reduces complex associations into $2 \mathrm{D}$ dimensions in which the correlations and anti-correlations between data points are measured and converted into relative distances (Glynn, 2010, p. 251). The values that are closely situated represent a strong correlation, whereas values that appear detached from each other suggest a weak correlation. The size of the data point represents the degree of the contribution of value in the structure of the data: the bigger the data point, the more important it is. BCA in this paper is utilized to visualize the correlations and anti-correlations between linguistic and social factors, which might otherwise go unnoticed.

The Log-linear analysis was chosen as the confirmatory tool for this study to test and confirm the clusters found in BCA. Log-linear can be understood as multiple chi-square tests to determine whether correlations are significant (Glynn, 2015). The mosaic plot of Log-linear analysis (Figure 3) simultaneously runs the four variables (the type of attitude, evaluation covertness, attitude polarity, and party affiliation) and shows the Pearson residual by the color and shading of each rectangle: cells with correlation are shaded blue and those with anti-correlation are shaded red. The absolute value of the residual is portrayed by shading density - cells with absolute values less than two are lightly filled, and those with absolute values above four are darker.

\section{Results}

\subsection{Representing Asylum Seekers in the Left- and Right-Wing Debates}

Different factors have been used in this study, namely affect, judgment, appreciation, evaluation covertness, attitude polarity, and party affiliations (see Table 1). These factors were chosen because they were expected to explain the discursive strategies employed by both left- and right-wing parties in this sample. Based on observations made during the annotation process, some factors awere collapsed to produce two sets of factors to function with the BCA. I combine party affiliations with attitude polarity and attitude type with evaluation covertness.

Table 1. Annotation schema

\begin{tabular}{ll}
\hline Explanatory factors & Values \\
\hline Affect & Inclination, Security, Satisfaction \\
Judgment & Esteem, Sanction \\
Appreciation & Social valuation, Reaction \\
Attitude polarity & Positive, Negative, Neutral \\
Evaluation covertness & Covert, Overt \\
Speaker political affiliation & Right, Left \\
\hline
\end{tabular}

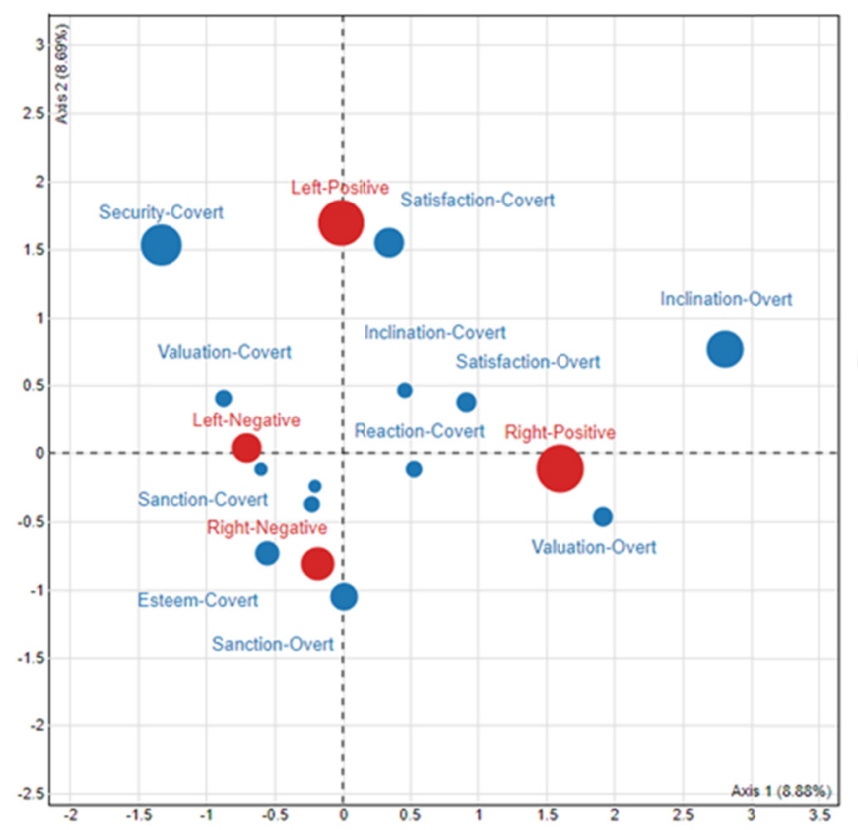

Figure 2. BCA: Correlation among party affiliations, attitude type, evaluation covertness, and attitude polarity 
Figure 2 presents the results of a BCA for all usage features. The plot creates four clusters of party affiliations and attitude polarity: Left-Positive, Left-Negative, Right-Positive, and Right-Negative. Distinct types of attitudes are correlated with these clusters. At the top of the plot, the cluster that is dominated by Left-Positive correlates with affect-Attitude (covert-security and Covert-satisfaction). On the left side of the plot, Left-Negative is associated with appreciation (covert-valuation). The third cluster is found at the bottom right of the plot: Right-Positive associated with appreciation-attitude (overt valuation, covert reaction). The last cluster in the bottom left of the plot is Right-Negative, correlated with judgment-attitude (covert/overt sanction, covert-esteem).

Cluster 1. Left-Positive: The left-wing party represents asylum seekers by using covert expressions of satisfaction and security to express positive emotions, which is illustrated in the following:

(11) Australia had a moral, a humanitarian and a national interest obligation to discharge our duties to rescue people in distress at sea, and that is what we did. Covert satisfaction (22/10/2009, Stephen Smith: MP, left-wing party)

(12) We have continued to work very closely with the Indonesian government and other near neighbors on the issue of ensuring that people do not seek to sail to Australia in leaky boats, putting their lives at risk, and enter Australia unlawfully. Covert security (15/05/2008, Chris Evans: senator, left-wing party)

Cluster 2. Left-Negative: The left-wing represents asylum seekers via covert social valuation, stressing a negative attitude:

(13) The government believes mandatory detention is essential, our border protection processes also include health, security and identity checks. We are, of course, concerned about the health and welfare of people in immigration detention. Covert valuation (08/02/2012, Joe Ludwig: senator, left-wing party)

Cluster 3. Right-positive: The right-wing represents asylum seekers using overt valuation and covert reaction in positive discourse, as exemplified in the following:

(14) It is this government that is taking genuine steps to clean up Labor's mess and put children into the community. Overt Valuation (27/08/2014, Michaelia Cash: senator, right-wing party)

(15) One hundred and seventy-nine people have been resettled - some of them have jobs; some of them are attempting to start businesses. Covert Reaction (01/09/2014, Scott Morrison: MP, right-wing party)

Cluster 4. Right-Negative: Asylum seekers are represented by overt/covert sanction and covert esteem to express a negative attitude:

(16) What those opposite need to understand is: this government will not provide permanent visas to those who arrived illegally by boat. Overt-sanction (23/06/2014, Scott Morrison: MP, right-wing party)

(17) I think the vast majority of asylum seekers in Australia will be people who have overstayed, got caught and thought: 'Uh-oh! Put in a protection visa claim.' Covert sanction (13/06/2006, Amanda Vanstone: senator, right-wing party)

(18) That is, processing by a review tribunal, processing of appeals by courts and arrangements to remove people who may have no entitlement to be here-who are not refugees. Covert-esteem (27/08/2002, Philip Ruddock: minister, right-wing party)

In summary, various expressions are utilized by both left- and right-wing parties to assert their positive or negative attitudes toward asylum seekers. The members of the left-wing party employ affectual values to express their positive discourse, whereas they use aesthetic values in their negative discourse. In their discourse, attitudes are always covertly expressed, as they tend to refer to the general phenomenon of the asylum rather than directly judging asylum seekers. The right-wing party expresses a positive attitude in praising the government acts toward asylum seekers using aesthetic qualities, while in the negative discourse, they use ethical and moral values to judge asylum seekers. In their discourse, attitudes are both covertly and overtly expressed.

\subsection{Predicting the Political Line}

Although the results of the BCA are strongly established and interpretable, we need to apply confirmatory statistics to read data beyond the sample and generalize about the discourse and attitude.

When submitting the same factors (attitude type, party, evaluation covertness, and attitude polarity), the mosaic plot reveals various correlations and anti-correlations. Several correlations found in the previous analysis have been confirmed:

1) The left-wing correlated with covert positive security, covert positive satisfaction, and covert negative valuation. 
2) The right-wing correlated with overt positive reaction and covert negative esteem.

Finally, Log-linear analysis has also confirmed distinct points elaborated in the correspondence analysis. The left-wing correlated with positive affect and negative appreciation, whereas the right-wing correlated with negative esteem and positive appreciation.

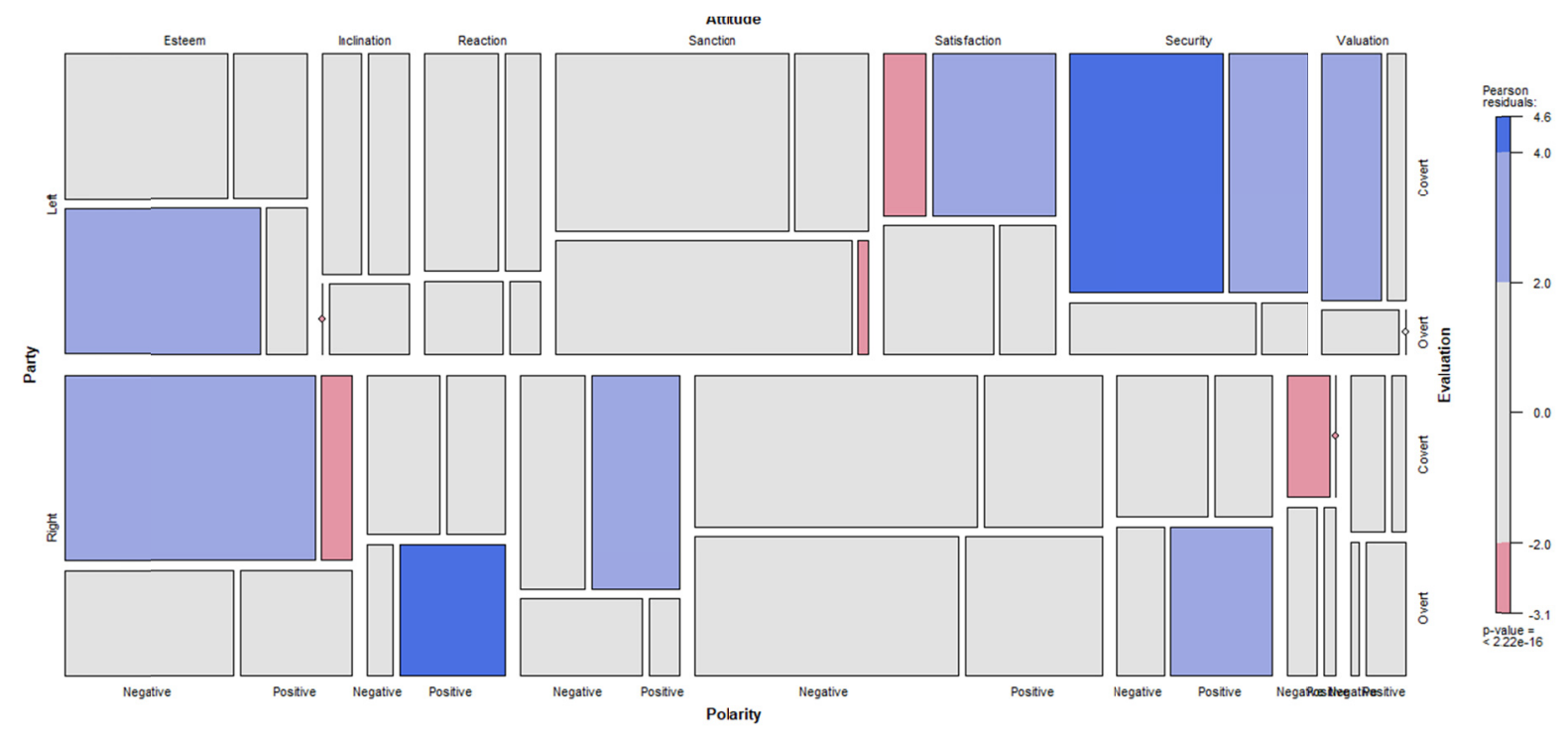

Figure 3. Mosaic plot display for the party, attitude type, evaluation covertness, and attitude polarity

\section{Discussion}

The purpose of the current study was twofold. First, it used the appraisal framework to account for the evaluative aspects of intra-party discourse in parliamentary debates and investigate how this attitudinal mechanism reveals politicians' ultimate ideological positioning. The frequent use of evaluative expressions to invoke rather than inscribe attitudinal assessment is a clear feature of political debates. The results of this study have also shown the potential function of implicit attitudinal expressions to unite the mass electorate in favor of a particular value position. Moreover, covert attitudes underlie party competition and conflicts about to domestic affairs as an attempt to obtain support or opposition. Second, the paper offers a new methodology to enhance the empirical and quantitative elements of CDA are enhanced. The results have shown that the behavioral profile approach can successfully be used to describe discourse. More importantly, they have illustrated that the method can depict the socially constitutive power of discourse as well as its socially conditioned practices.

The results highlight the distinction between left and right based on the choice of evaluative meanings in political language. In the debates, both the left and the right are engaged in positive affectual discourse (emotional evaluation of an entity). In deploying affectual discourse, both the left and the right aim to appraise the positive in-group image (party agenda) because the main interest of the speakers is to align themselves with their listeners - the electorate - based on shared feelings and values. The emotional discourse can also be interpreted as a reaction to the challenging questions posed by the opponent. On the other hand, the negative discourse relates more to the aesthetic evaluation of things and processes; for instance, both the left and the right evaluate asylum seekers' condition in terms of health, identity, or economic circumstances (Coffin \& O'Halloran, 2006) victimizing them. Victimization may be understood as taking a humanitarian perspective to address the migration issue (van Dijk, 1997; Khosravinik, 2009). The discourse of the right is differentiated from that of the left as it highlights the negative evaluation of human behavior from an ethical standpoint (judgment in appraisal), for instance, judging the asylum seekers based on ethical and moral values. The representation of asylum seekers is centered on their possession of undesirable characteristics, belonging to a different culture, and being violators of the law (e.g., smuggling and illegally crossing borders). Asylum seekers are described as a "threat" to the culture, values, and history of Australia. This fits in with the narrative of the difference between "US" and "THEM" (van Dijk, 2000; van der Valk, 2003). Both left- and right-wing parties attempt to display their emotional commitments in threatening situations (the migration issue) to show that they are personally concerned with maintaining values and, in particular, to legitimate their discourse because "a legitimizing discourse is needed to legitimize moral 
evaluations" (van Leeuwen, 2008, p. 21).

The findings of this study reveal that the distinction between left and right is challenged specifically by signaling the covert/implicit evaluative meaning in political language. Whereas the right-wing shifts from overtness to covertness in its attitudinal basis, the left-wing is highly grounded in covertness. This shows a difference in subjectivity and personalization (Bednarek, 2009) and, consequently, a distinction in the emotional responses of the listeners. The right-wing is more focused on individualizing their personal responses, while the left-wing succeeds at backgrounding or denying their attitude basis as well as shifting their evaluation interest from humans to the entity or state being evaluated. Previous research has shown that the choice of evaluative expressions is not always "clear," and when it is combined with covertness, evaluation, can only strengthen the ideological views of politicians. As White explains, "the more implicitly evaluative mechanisms are of particular interest to those concerned with ideology in that they provide means by which particular points of view and value orientations can be made to seem to arise naturally from apparently 'factual' informational content" (2006, pp. 65-66).

This study also underscores the importance of the distinction between left- and right-wing when dealing with the controversial topic of asylum and migration discourse in major political conflicts. It also confirms that party positioning regarding the representation of asylum seekers continues to be structured on a left-to-right spectrum. Previous studies highlight that those from left-wing political backgrounds view migrants positively, whereas those from the right-wing are less in favor of ethnic minorities (van Dijk, 1997). However, this study revealed that the ideological positioning of the left- and right-wings is not as simple as it may appear. Different discursive strategies such as the type of evaluative language and its covertness, the contextual factors (evaluating asylum seekers' conditions in terms of health or economy, defending the policy, praising one's agenda, etc.) play a prominent role in profiling the ideology of the left and right portions of the spectrum.

\section{Conclusion}

This study showed how the appraisal framework can be used as an analytical tool to depict attitudes in intraparty discourses.Tthe main objective was to demonstrate the feasibility of the behavioral profile approach to improve CDA methodology. Therefore, the contextual manual annotation of examples and the descriptive and confirmatory statistical analysis aim to improve the otherwise potentially biased interpretation of CDA. The primary and critical strength of analyzing the results via multivariate statistics is that it enables addressing the complexity of the interactions between different dimensions, permits hypothesis testing, and produces verifiable results to answer research questions (Glynn, 2015), which are not easily approached using traditional CDA methods. The benefits of using statistics in CDA include their importance in developing the explanation stage in the CDA process, which is criticized as being subject to the discourse analyst's prejudices and biases. This study remains proof-of-principle that quantification is a powerful method in addition to socially critical lines of research.

The distinction between "left" and "right" politics should not be taken for granted as two separate sets of fixed ideas. The statistical analysis showed that much evaluative language is shared between right and left parties. This is not to say that left and right political terms are devoid of meaning, but rather that left and right politics can change over time and from one generation to another (Bobbio, 1996).

The results presented in this paper should be viewed as pilot research on the use of evaluative language to determine political positioning based on White's (2006) claim that appraisal is more than an analytical tool and can precisely account for ideology in discourse. However, the scope of the study is limited exclusively to attitude in the appraisal framework. Therefore, future studies should test the potential of other evaluative resources such as engagement and graduation. In addition to verbal strategies, the study of multimodal features of parliamentary discourse is also very promising for future research because parliamentary discourse is increasingly multimodal.

\section{Acknowledgments}

I would like to thank Nele Põldvere for offering constructive and valuable comments on an earlier draft of this article.

\section{References}

Antelmi, D., \& Santulli, F. (2010). The presentation of a new Government to Parliament from ritual to personalisation. In C. Ilie (Ed.), European Parliaments under Scrutiny (pp. 111-134). Amsterdam. Benjamins. https://doi.org/10.1075/dapsac.38.07ant

Baker, P. (2004). 'Unnatural Acts': Discourses of homosexuality within the House of Lords debates on gay male law reform. Journal of Sociolinguistics, 8(1), 88-106. https://doi.org/10.1111/j.1467-9841.2004.00252.x

Baker, P., Gabrielatos, C., Khosravinik, M., Krzyżanowski, M., McEnery, T., \& Wodak, R. (2008). A useful 
methodological synergy? Combining critical discourse analysis and corpus linguistics to examine discourses of refugees and asylum seekers in the UK press. Discourse \& Society, 19(3), 273-306. https://doi.org/10.1177/0957926508088962

Bayley, P. (Ed.). (2004). Cross-cultural perspectives on parliamentary discourse (p. 10). Amsterdam. Benjamins. https://doi.org/10.1075/dapsac.10

Bednarek, M. (2006). Evaluation in media discourse: Analysis of a newspaper corpus. A\&C Black.

Bednarek, M. (2009). Language patterns and ATTITUDE. Functions of Language, 16(2), 165-192. https://doi.org/10.1075/fol.16.2.01bed

Bevitori, C. (2005). Attribution as evaluation: A corpus-based investigation of quotations in parliamentary discourse. ESP Across Cultures, 2, 7-20.

Biber, D., \& Finegan, E. (1989). Styles of stance in English: Lexical and grammatical marking of evidentiality and affect. Text-Interdisciplinary Journal for the Study of Discourse, 9(1), 93-124. https://doi.org/10.1515/text.1.1989.9.1.93

Bobbio, N. (1996). Left and right: The significance of a political distinction. University of Chicago Press.

Carbó, T. (1992). Towards an interpretation of interruptions in Mexican parliamentary discourse (1920-1960). Discourse \& Society, 3(1), 25-45. https://doi.org/10.1177/0957926592003001002

Carbó, T. (2004). Parliamentary discourse when things go wrong. In P. Bayley (Ed.), Cross-Cultural Perspectives on Parliamentary Discourse (pp. 301-337). Amsterdam. Benjamins. https://doi.org/10.1075/dapsac.10.09car

Chilton, P. (2005). Missing links in mainstream CDA. In R. Wodak \& P. Chilton (Eds.), A New Agenda in (Critical) Discourse Analysis (vol. 13, pp. 19-51). Amsterdam. Benjamins. https://doi.org/10.1075/dapsac.13.05chi

Chilton, P., \& Schäffner, C. (Eds.). (2002). Politics as text and talk: Analytic approaches to political discourse (Vol. 4). John Benjamins Publishing. https://doi.org/10.1075/dapsac.4

Coffin, C., \& O'Halloran, K. (2006). The role of appraisal and corpora in detecting covert evaluation. Functions of Language, 13(1), 77-110. https://doi.org/10.1075/fol.13.1.04cof

Eggins, S. (2004). Introduction to systemic functional linguistics. A\&C Black.

Fairclough, N. (1992). Discourse and social change (Vol. 10). Cambridge: Polity Press.

Fairclough, N. (2001). Language and power. Pearson Education.

Fairclough, N., \& Wodak, R. (1997). Critical discourse analysis. Discourse Studies: A Multidisciplinary Introduction, 2, 258-284.

Fowler, R. (1991). Language in the news: Discourse and ideology in the press. London: Routledge.

Gabrielatos, C., \& Baker, P. (2008). Fleeing, sneaking, flooding: A corpus analysis of discursive constructions of refugees and asylum seekers in the UK press, 1996-2005. Journal of English Linguistics, 36(1), 5-38. https://doi.org/10.1177/0075424207311247

Geeraerts, D., Grondelaers, S., \& Bakema, P. (1994). The structure of lexical variation. A descriptive framework for cognitive lexicology. Berlin: Mouton de Gruyter. https://doi.org/10.1515/9783110873061

Glynn, D. (2015). The socio-cultural conceptualisation of FEMININITY Corpus evidence for Cognitive Models. In Empirical Methods in Language Studies (pp. 97-117). Peter Lang.

Glynn, D., \& Fischer, K. (Eds.). (2010). Quantitative methods in cognitive semantics: Corpus-driven approaches (Vol. 46). Walter de Gruyter. https://doi.org/10.1515/9783110226423

Glynn, D., \& Robinson, J. A. (Eds.). (2014). Corpus methods for semantics: Quantitative studies in polysemy and synonymy (Vol. 43). John Benjamins Publishing Company. https://doi.org/10.1075/hcp.43

Gries, S. T., \& Stefanowitsch, A. (Eds.). (2007). Corpora in cognitive linguistics: Corpus-based approaches to syntax and lexis (Vol. 172). Walter de Gruyter. https://doi.org/10.1515/9783110197709

Gruber, H. (2012). Establishing Intertextual references in Austrian parliamentary debates. In A. Fetzer, E. Weizman \& E. Reber (Eds.), Follow-ups in Political Discourses: Exploration across Contexts and Discourse Domains (pp. 25-55). Amsterdam: Benjamins. https://doi.org/10.1075/dapsac.60.02gru 
Ilie, C. (1999). Question-response argumentation in talk shows. Journal of Pragmatics, 31(8), 975-999. https://doi.org/10.1016/S0378-2166(99)00056-9

Ilie, C. (2003). Discourse and metadiscourse in parliamentary debates. Journal of Language and Politics, 2(1), 71-92. https://doi.org/10.1075/jlp.2.1.05ili

Ilie, C. (2004). Insulting as (un) parliamentary practice in the British and Swedish parliaments. Cross-Cultural Perspectives on Parliamentary Discourse, 10, 45. https://doi.org/10.1075/dapsac.10.02ili

Ilie, C. (2005). Politeness in Sweden: Parliamentary forms of address. Politeness in Europe, 127, 174. https://doi.org/10.21832/9781853597398-014

Ilie, C. (Ed.). (2010). European parliaments under scrutiny: Discourse strategies and interaction practices (Vol. 38). John Benjamins Publishing. https://doi.org/10.1075/dapsac.38

Jakaza, E., \& Visser, M. W. (2016). Argumentation and appraisal in divergent Zimbabwean parliamentary debates. In D. O. Orwenjo (Ed.), Political Discourse in Emergent, Fragile, and Failed Democracies (pp. 126-142). IGI Global. https://doi.org/10.4018/978-1-5225-0081-0.ch007

KhosraviNik, M. (2009). The representation of refugees, asylum seekers and immigrants in British newspapers during the Balkan conflict (1999) and the British general election (2005). Discourse \& Society, 20(4), 477-498. https://doi.org/10.1177/0957926509104024

KhosraviNik, M. (2010). The representation of refugees, asylum seekers and immigrants in British newspapers: A critical discourse analysis. Journal of Language and Politics, 9(1), 1-28. https://doi.org/10.1075/jlp.9.1.01kho

Martin, J. R., \& White, P. R. R. (2005). The evaluation of language: Appraisal in English. Hampshire: Palgrave Macmillan. https://doi.org/10.1057/9780230511910

Mautner, G. (2005). Time to get wired: Using web-based corpora in critical discourse analysis. Discourse \& Society, 16(6), 809-828. https://doi.org/10.1177/0957926505056661

Halliday, M. A. K., \& Matthiessen, C. M. I. M. (1999). Construing Experience through Meaning: A Language-Based Approach to cognition. A\&C Black.

Hart, C. (2010). Critical discourse analysis and cognitive science: New perspectives on immigration discourse. Springer. https://doi.org/10.1057/9780230299009

Hart, C. (2014). Discourse, grammar and ideology: Functional and cognitive perspectives. Bloomsbury Publishing.

Hunston, S. (2010). Corpus approaches to evaluation: Phraseology and evaluative language (Vol. 13). Routledge. https://doi.org/10.4324/9780203841686

Hunston, S., \& Thompson, G. (Eds.). (2000). Evaluation in text: Authorial stance and the construction of discourse: Authorial stance and the construction of discourse. Oxford University Press.

Rojo, L. M., \& Van Dijk, T. A. (1997). “There was a problem, and it was solved!”: Legitimating the expulsion of illegal migrants in Spanish parliamentary discourse. Discourse \& Society, 8(4), 523-566. https://doi.org/10.1177/0957926597008004005

Slembrouck, S. (1992). The parliamentary Hansard 'verbatim' report: The written construction of spoken discourse. Language and Literature, 1(2), 101-119. https://doi.org/10.1177/096394709200100202

Van der Valk, I. (2000). Parliamentary discourse on immigration and nationality in France. In T. A. van Dijk \& R. Wodak (Eds.), Racism at the Top: Parliamentary discourses on ethnic issues in six European states (pp. 221-260). Klagenfurt: Drava Verlag.

Van Der Valk, I. (2003). Political discourse on ethnic minority issues: A comparison of the right and the extreme right in the Netherlands and France (1990-1997). Ethnicities, 3(2), 183-213. https://doi.org/10.1177/1468796803003002002

Van Dijk, T. A. (1991). Discours de l'élite et racisme. Cahiers de praxématique, 17, 49-71. https://doi.org/10.4000/praxematique.3125

Van Dijk, T. A. (1993). Elite discourse and racism. Sage. https://doi.org/10.4135/9781483326184

Van Dijk, T. A. (1995). Power and the news media. Political Communication and Action, 6(1), 9-36.

Van Dijk, T. A. (1997). Political discourse and racism: Describing others in Western parliaments. The Language 
and Politics of Exclusion: Others in Discourse, 2, 31-64.

Van Dijk, T. A. (2000). Ideology and discourse: A multidisciplinary introduction. Barcelona: Pompeu Fabra University.

Van Leeuwen, T. (1996). The representation of social actors. In C. R. Caldas-Coulthard \& M. Coulthard (Eds.), Text and practices: Readings in critical discourse analysis (pp. 32-70). London: Routledge.

Van Leeuwen, T. (2008). Discourse and practice: New tools for critical discourse analysis. Oxford University Press. https://doi.org/10.1093/acprof:oso/9780195323306.001.0001

Van Leeuwen, T., \& Wodak, R. (1999). Legitimizing immigration control: A discourse-historical analysis. Discourse Studies, 1(1), 83-118. https://doi.org/10.1177/1461445699001001005

White, P. R. (2006). Evaluative semantics and ideological positioning in journalistic discourse. In I. lassen, J. Strunk \& T. Vestergaard (Eds.), Mediating ideology in text and image: Ten critical studies (pp. 37-67). Amsterdam: Benjamins. https://doi.org/10.1075/dapsac.18.05whi

White, P. R. (2015). Appraisal theory. In K. Tracy, C. Ilie \& T. Sandel (Eds.), The international encyclopedia of language and social interaction (pp. 1-7). Wiley-Blackwell. https://doi.org/10.1002/9781118611463.wbielsi041

White, P. R. R. (2002). Appraisal-the language of evaluation and stance. John Benjamins.

Widdowson, H. G. (1995). Discourse analysis: A critical view. Language and Literature, 4(3), 157-172. https://doi.org/10.1177/096394709500400301

Wodak, R., \& Reisigl, M. (2001). The Semiotics of tacism. Approaches in critical discourse analysis. Passagen Verlag. https://doi.org/10.4135/9780857028020

Wodak, R., \& Van Dijk, T. A. (2000). Racism at the top. Drava.

\section{Copyrights}

Copyright for this article is retained by the author, with first publication rights granted to the journal.

This is an open-access article distributed under the terms and conditions of the Creative Commons Attribution license (http://creativecommons.org/licenses/by/4.0/). 